\title{
Towards Affordable Low Cost Housing: Strategies of Low Cost Housing Development for the Low Income Population in Rwanda
}

\author{
Jean Bosco Harelimana ${ }^{1^{*}}$ \\ ${ }^{1}$ Institut d'Enseignement Superieur de Ruhengeri, Musanze, Rwanda
}

\begin{abstract}
Received: August 23, 2017; Accepted: September 30, 2017; Published: November 30, 2017
*Corresponding author: Jean Bosco Harelimana, Institut d'Enseignement Superieur de Ruhengeri, Musanze, Rwanda. P.O.B. 155
\end{abstract}

Email: harelijordan@yahoo.fr

\begin{abstract}
The issue of affordable housing remains to be interested to the researchers all-over the world. Like elsewhere, in Rwanda the modern technology is being used in housing building towards more affordable house low cost. However, the constraints to obtain affordable houses are still experiencing on Rwanda market and can be regarded as financial, cultural, social, historical and institution framework. The high cost of capital, the high price to rent and to own affordable houses remains to be the main challenge for younger professionals and new tenants. On other side, high loan and mortgage interest rates hindering ownership of affordable houses for the middle and low income household sectors. As illustrated under section of discussions, consumer attitude/culture and level of income are the main factors towards affordable house. However, the Rwandan government may attract foreign investors such United Nations agencies, development banks, international NGOs, public and private partnership, World Bank and derivatives in their program to fund affordable housing in order to reduce the cost of capital and make it easier for all categories towards affordable housing.
\end{abstract}

Keywords: Affordable Housing, Finance, Strategies, Challenges, Low Cost Housing.

\section{Introduction}

When it comes to the health and vitality of our communities, affordable housing is the key. The need for quality, affordable homes is an important part of Sustainable Development Goals and the Rwandan vision 2050 as it seeks to evolve into a sustainable community. With the economic issues the world is facing the demand for affordability is greater than ever before [10,17].

The issue of housing affordability is becoming a more concern for several researchers in many worlds in Africa as well as in Rwanda $[1,8,9,10,14,17]$. The poor management of the growth of housing cost has been affecting negatively any African society in terms of finance. Therefore, reducing the effect of housing issues could be a potential benefit to both low and middle income households. According to Parrillo, one of the social problems includes housing where it brings issues due to various social, economic and cultural implications [12]. As seen above, the matter of housing issues is threatening low and middle income society [2]. In these circumstances the housing issue is one of the most disturbing structural and functional social problems, with certain cultural aspect. This has been becoming a constraint for some middle-income groups, whereas it had previously mainly been an issue for those on lower incomes.

Thus, the aim of this paper is to identify the actual challenges and way forward related to the affordable and low cost housing. Based on secondary data from previous studies, this study measures different issues namely loan availability, housing affordability, housing scheme's policy, consumer attitude, neighborhoods, housing quality, economic development. Therefore, it is hoped that the results and discussion of this paper would help to instill more understanding of the real issue related to housing. Because proper knowledge in identifying the main issue of affordable housing can assist the government of Rwanda and stakeholders to handle and effectively resolve these issues, which might affect the citizen as well as the whole county health. Indeed, it clear that though may require more effort from both public and private sectors but working together could lead to low cost affordable housing. For instance, government should provide grants as subsidiaries to soften high loans and mortgage interest rate which would encourage actors to borrow money and invest in affordable housing on low cost.

\section{Literature Review}

The modern technology has been involved in housing building towards more affordable house low cost. For instance Nabutola argued that compressed earth block technology along with using simple materials and simple construction technique have offered the people in Rwanda the ability to construct a simple, efficient and cost-effective house [10,17]. This simple house has more advantages of a concrete block construction without the cost. Furthermore, CBC added that low cost materials are locally available, affordable and therefore, because of innovation and technology the poor families who constitute high portion of population can afford low cost houses [3]. 
Indeed, most architects have received some training in design solution for building and construction that use conventional approaches, including low incoming project.

\section{Actors and practices of low cost building materials and technologies}

More research and development have been conducted for low cost building materials and technologies all over the world by involvement of many organisations both national and international, as well as non-governmental organisations.

The general speaking here was to lowering construction costs, especially in regard to housing in order to make it affordable to more people who predominantly in the low income households $[9,10,17]$.

\section{Challenges in the Provision of Affordable Housing in Rwanda}

The main constraint to obtain affordable houses can be regarded as financial, social and institution framework [15]. The financial factors tackle middle economy in the country, high cost of infrastructures, low level investments, difficulties in accessing financial resources and escalating cost of building materials. All these factors illustrated above make it tough for poor and middle class to afford house. The challenges do not only include financial factors but also social factors such as population explosion, rapid-rural to urban migration and high poverty levels. As cited by Daniel, institutional frameworks including housing policies in place have failed to help a conclusive environment for investment in affordable housing [6]. Indeed, the land in urban areas in Rwanda has been raised in recent years. The speedy influx of people to the urban areas has generated high demand for land causing prices in residential areas to increase so fast.

In order to identify the key challenges in the provision of affordable housing in Rwanda the study will consider the key aspects involved in the provision of affordable housing, as discussed below:

\section{Land}

In urban areas, land has been highly valued and is mostly in hands of the central government and the local authorities. The other landowners are speculators who looking to make a quick cash.

This has made land inaccessible to the more people including poor and middle class who need it most but cannot afford premium price. Indeed, according to Nabutola the high demand of land with competing interest groups and individuals has pushed prices up $[10,17]$.

\section{Financial Resources for Housing}

The financial bottle neck is a major limitation factor in housing development. The sources of funds are few and the funds are on high price. Getting qualified for mortgages are still too severe despite the fact that housing is still in short supply. Renaud estimated that Inappropriate fiscal policies on real estate financing, inability to finance house loans to groups, low affordability due to poverty, high interest rates on mortgages, absence of graduated payments of mortgages and lack of access to the large deposits of retirement benefit funds have hindered the development of the housing sector [16].

The financial set up in the housing market in Rwanda as indeed elsewhere is such that those offering funding seek to make a profit and declare dividends for the shareholders because that is what they are in business for. The money market is expensive due to relatively higher risks that raise interest rates.

\section{Public-Private Partnership in Housing Delivery}

The common objective of public-private partnership in housing delivery is to boost the productivity of housing sector, increasing housing affordability and improve access to basic infrastructure. Ikekpeazu mentioned that in order to achieve the desired output of public-private partnership, the discernment of the housing sector as a vast arena of social problems and a drain on the economy must change [7]. Housing must be considered as significant economic sector with vital linkages to the overall economy of a country.

\section{Investment in affordable housing supports multiple social objectives}

The evidence shows that investment in affordable housing supports multiple social objectives. This includes improvements to individual outcomes such as employability, crime, health and wellbeing and community cohesion. It is particularly important to assess the socio-economic impact of building affordable homes in light of the large set of households where demand for affordable homes cannot currently be met [9].

Indeed, this wide set of desirable socio-economic outcomes cannot be achieved through Housing Benefit or other operating expenditure on affordable housing alone. This is because many of these benefits are the result of affordable housing being better able to meet tenants' needs than alternatives such as housing in the private rented sector. Therefore public investment in affordable housing is vital $[10,17]$.

As result of investing in affordable housing, it will generate more opportunities for both actors and tenants. For instance, more unemployed people can get job opportunities and tenants could benefit from poorly insulated private sector home to a good quality, insulated affordable home would be less at risk of suffering from hygienic diseases and therefore, could save household expenditure that would be spent on those diseases.

\section{Methodology}

The study has used primary and secondary data affordable and low cost housing measurements that collected from previous studies. Affordable housing and its trends were illustrated in details through critical review of literature. This study focused on the different criteria for affordable and low cost housing assessment. The same study arranged these criteria that indirectly impact affordable housing by examining each of their functions. 


\section{Results And Discussions}

As depicted above, this study discussed some affordable housing trends using primary and secondary data filtered from previous studies. Different criteria have been discussed in depth in order to provide significant overview about affordable housing.

\section{Strategies in place of driving to words low cost affordable housing}

The proposed strategies will be vehicles to enable affordable housing providers to access lower cost debt for longer terms unlocking desperately needed "fit-for-purpose" funding into the sector in Rwanda.

To access the lower cost capital it requires the government, private sector, institutional investors and non-profit organizations to work together in new and collaborative ways [Figure 1].

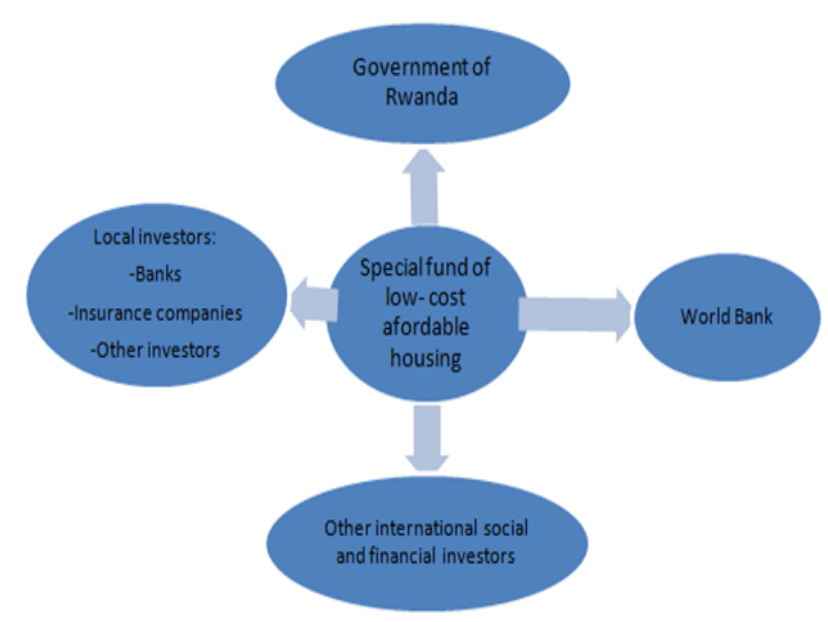

Figure 1: Low cost affordable housing Model

This model is a viable solution that, with Government support and institution investors in the line of Public Private Partnership could greatly contribute to increasing the stock of affordable housing across the country. The model would allow housing providers to access funding at lower interest rates and for longer terms. The benefits of this financial model include:

1. Housing providers would have access to capital which is more fit-for-purpose, that is over longer term (of 15-25 years) and on lower cost terms.

2. Institutional investors will have a financing vehicle to achieve long term secure and stable returns as part of their portfolio whilst also supporting the affordable housing. The fund would have investment characteristics such as a Government-backed credit rating with appropriate risk adjusted returns that are similar to other asset classes that institutional investors are familiar with

\section{Possible Ways of achieving low cost and affordable housing in Rwanda}

This section offers a set of strategies that can be used in Rwanda to increase affordability while maintaining commercial viability. These strategies are not a formula, but suggested ingredients that we expect will improve the chances of success.

\section{Strategy 1: Using simple materials and simple construction techniques}

Currently, in Rwanda, some Actors are using simple materials and simple construction techniques to afford low cost houses. Indeed, with compressed earth block technology, people can construct a simple, efficient, cost-effective house as it shown below: [Picture 1].

This house will have all the advantages of concrete block construction without the costs. To achieve good results, however, some new construction techniques have been learned and simple machines and some tools are used to compress blocks. [Table1, Picture2].

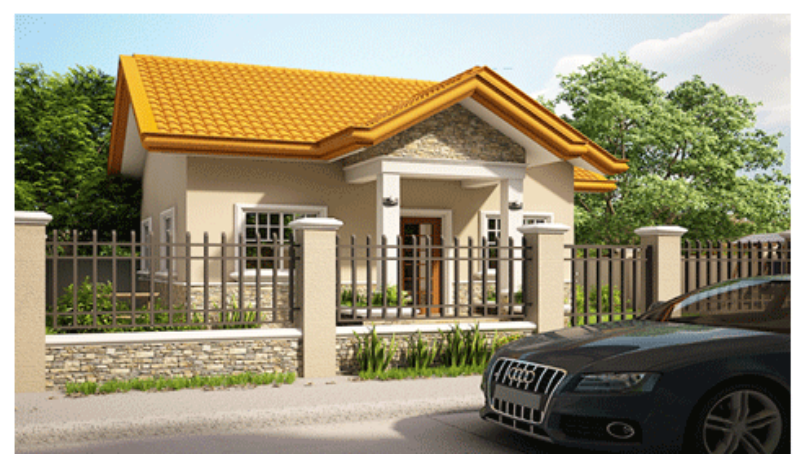

Picture 1: Low cost affordable house of 18 Million Rwandan francs

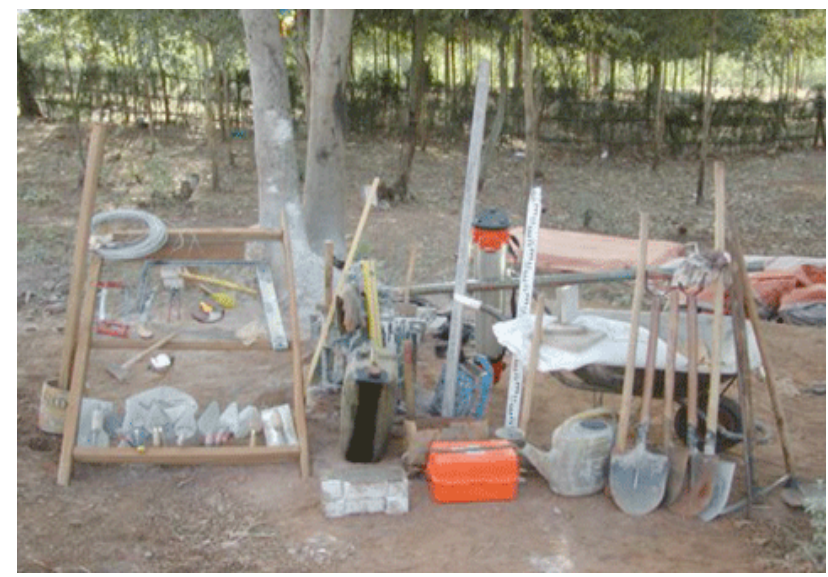

Picture 2: Tools to presses blocks in local raw materials 
Table 1: List of tools used to compress blocks

\begin{tabular}{|c|c|c|c|}
\hline - $\quad$ Shovels & - Wire & - Wheelbarrow & - $\quad$ Eye protection \\
\hline - $\quad$ Picks & - $\quad$ Pliers & - $\quad$ Calculator & - $\quad$ Carpenter square \\
\hline - Watering can & - $\quad$ Rubber gloves & - $\quad$ Chisels & - $\quad$ Measuring tape \\
\hline - $\quad$ Oil & - $\quad$ Metal saw & - $\quad$ Trowels & - Wood Saw \\
\hline \multirow[t]{2}{*}{ - $\quad$ Sieve } & - $\quad$ String & - $\quad$ Surveyors level & - $\quad$ Block press \\
\hline & & & - Hammers \\
\hline
\end{tabular}

There are many different types of block presses. Some are manually operated and others are powered with electricity or petroleum. Manual presses are operated by semi-skilled workers, whereas powered machines need more skilled operators and are more expensive to run. [Picture 3, Picture 4].

Bricks are either square or flat faced and they may interlock. This Interlocking blocks offer an advantage of requiring less (or no) mortar in joint of blocks. Square blocks are more versatile for making curves or intersection walls, as are conventional bricks.

However, In case no machine is available, a simple compressed earth block is produced with the help of a mold and a tool to ram the earth into the mold. If an appropriate mix is used and the bricks are well mixed and uniformly compressed, better strength is achieved than using traditional molding techniques. However this technique is not consistent and does not achieve the same results as a machine press. Furthermore, this method has some downside of being very slow and only producing flat faced as shown in the picture below. [Picture 5].

The affordability issue continues to be a serious problem for people who keep the Kigali and other cities running such as cleaners and students and other people with low income jobs. But it's also becoming a problem further up the income scale. House prices in Kigali rose by $47 \%$ between 2012 and 2016 compared to $24 \%$ in other cities like Musanze, Gisenyi, Muhanga, Rwamagana and Huye.

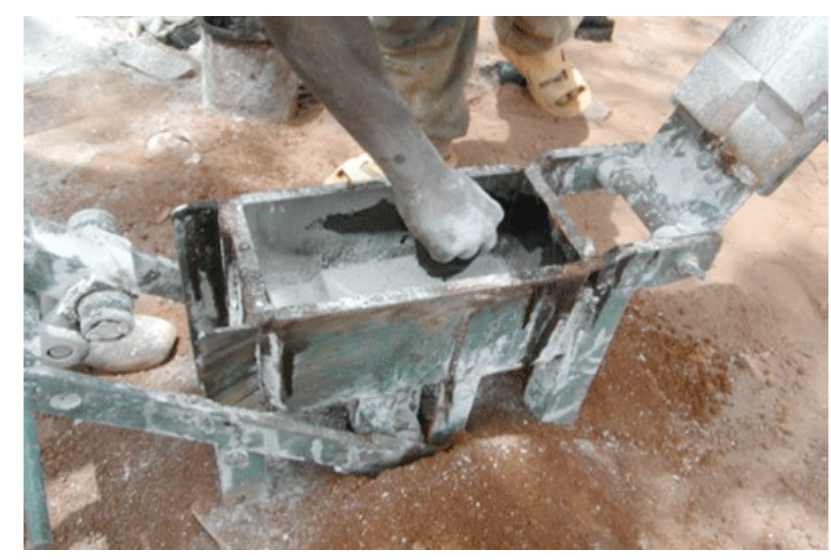

Picture 3: Manual presses machine

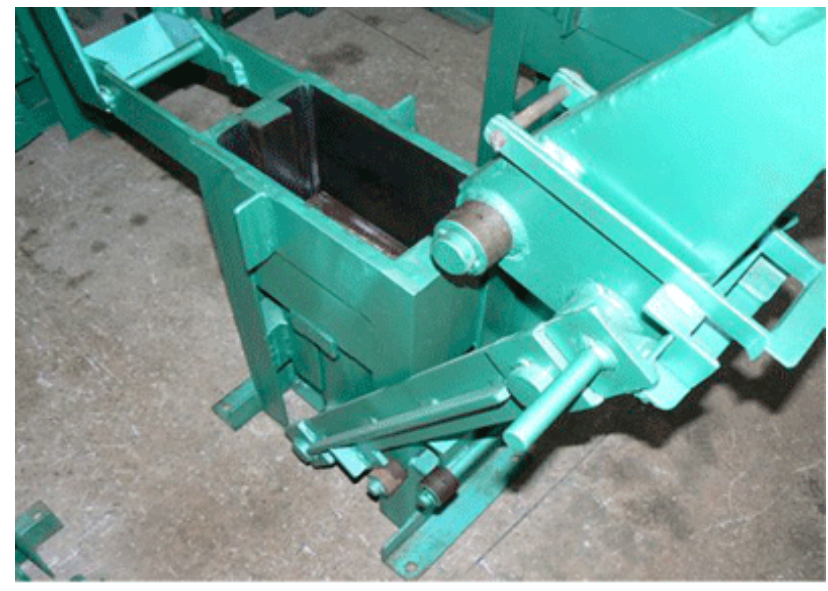

Picture 4: Electrical presses machine

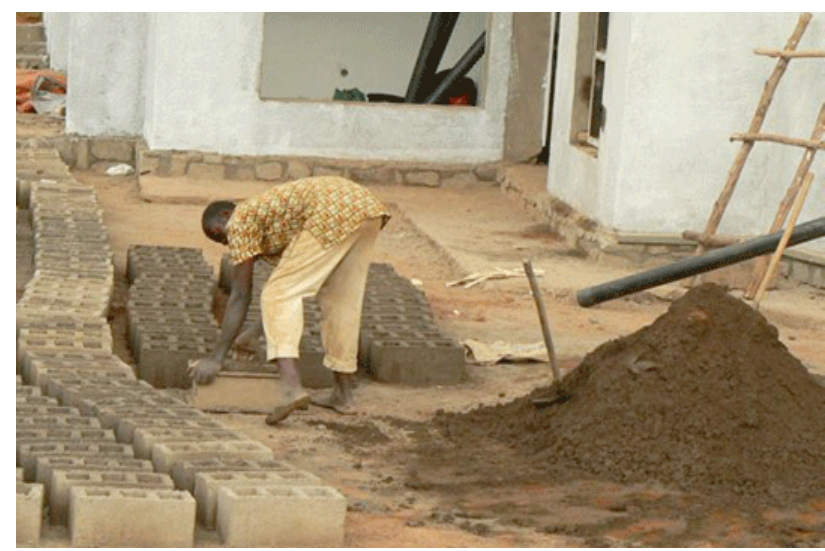

Picture 5: Priced out; the challenges for young professionals

As extracted by Nabutola average rents increased by $22 \%$ in Kigali and $15 \%$ in other cities over the same period $[10,17]$. However, over the same period wages have failed to rise at significant level, with increases by only $7 \%$. Considering the average earning and comparing it to average rents, the analysis of this study shows that only few boroughs are affordable for people with middle and low income who renting a one-bedroom house with medium standards especial in Kigali. 


\section{Strategy 2: Make land affordable}

Land is so expensive in urban Kigali that it alone can make affordable housing unviable. Additionally, banks in Rwanda are reluctant to finance the purchase of land. Therefore creative methods often need to be used to secure land in a way that makes sense for the project. Below are a few possibilities:

\section{Land as equity:}

Find a land partner who can come in with the land as equity. This means eventually paying for the land in the form of dividends, which may align nicely with cash flows since revenue comes in first and the whole payment does not need to be made at once.

\section{Concessionary land:}

Find an organization or government agency with an interest in low cost housing and receive the land at a concessionary rate. This is currently happening in Rwanda on land that belongs to RSSB. A low-income housing development is being planned on their land, enabling the project to have much more flexibility with pricing than is typical because the land is free. This same scenario could be replicated on government land or land belonging to individual owners with an interest in affordable housing.

\section{Land banking/Flipping land:}

Buying more land than is needed for the project and reselling it at an increased price can dramatically reduce the net cost of the land. Assuming significant appreciation of land value continues to be the trend, this can even make the land essentially free. However, it does not solve the challenge of financing the land since the initial purchase still needs to happen upfront.

\section{Strategy 3: Alternative Technologies}

Using alternative technologies can be challenging in the Rwandan market, but if done correctly it has the potential to be an essen 7 tial piece of bringing down the cost. The most important aspect to be aware of is ensuring that the look and feel of the home is similar, if not the same, as traditional techniques. When some $\neg$ one purchases a home, whether they are rich or poor, they want to put their savings into old-fashioned brick and mortar rather than a shiny new technology that is untested and unfamiliar.

\section{Strategy 4: Creative Financing}

Given the unfriendly nature of the lending climate in Rwanda, it can be hugely beneficial to think creatively about how to raise funds. Looking to international lenders for finance is one way to address this problem. Development Finance Institutions (DFIs) and other International Organizations can be sources of project finance with single digit interest rates. This reduced cost of capital (especially in such capital intensive and highly leveraged projects) can make a big difference in the final unit price.

\section{Strategy 5: Subsidy \\ Government Subsidy:}

Cashing in on the subsidies offered by the government seems straightforward, but many developers seem unaware of what is offered, or simply disillusioned that it will be delivered. Therefore, it is important to be familiar with the incentives and the path to benefit from them.

\section{Building subsidy into your model:}

While the best scenario is a development where every unit is profitable, this is not always possible if the goal is to cater to low-income populations. Therefore, the choice to incorporate cross-subsidy is worth considering. This can be in the form of traditional cross-subsidy, where the affordable units make a loss that is subsidized by middle-income units. Or the affordable units can make a small margin while middle-income units make a larger margin. Either scenario creates a mixed-income development. Many housing experts believe that in order for affordable housing to be financially viable, especially in an urban setting and without alternative technologies, mixed-income is the only way to go.

\section{Strategy 6: Design}

Innovative designs and layouts can help to use space efficiently and effectively. There have been many interesting experiments with creative designs for affordable housing communities that save on cost and space as well as create more community interaction and reduce the risk of ghettoization. Most afford $\neg$ able housing communities that fail to increase quality of life do so because master planning and design were overlooked. They ignore the benefits of creating mixed-use developments with community spaces and commercial areas. The importance of design should not be underestimated!

\section{Strategy 7: Incremental construction}

In some contexts incremental construction increases the ability to provide homes at an affordable rate. An Acumen Fund portfo $\neg$ lio company in Pakistan, Ansaar Management Company (AMC), provides an example of successful, developer-led, incremental construction.

AMC's model entails constructing and selling homes block by block to avoid the large amounts of capital needed at one time to build in the traditional fashion. This means that economies of scale are not achieved and therefore the profit per home is less than a traditional model. But in exchange for a lower margin, AMC is able to recycle capital and spread out demand, and the profits made from each block can be used to fund the construction of the next block.

\section{Strategy 8: Self construction}

Self-construction refers to homeowners driving the construction of their own homes, which allows them to work within their own financial require $\neg$ ments and timeframe. Selfconstruction can be integrated into a model in a variety of ways. It can range from a private sector version of the "site and services" model (infrastructure and foundations are provided, and the homeowner purchases a plot and builds their own home) to a simple ground floor structure constructed by the developer, leaving residents with the ability to expand as their financial situation allows. 
The key to successful homeowner-led incremental construction is ensuring the quality of the construction both to maintain the look and feel of the development and to maintain safety standards. This can be challenging and requires a strong ongoing role from the developer or other affiliated agency, sometimes in the form of technical assistance through engineering and design support.

\section{Strategy 9: Community supported labor}

Labor costs can be cut by hiring the current or future residents as construction labor. This strategy was used by different investors and allowed them to both cut costs and to increase the residents' feeling of ownership in the project. However, it is worth noting that it may take more management and is only viable for certain project designs and construction techniques. Usually the community workers must also be accompanied by skilled labor.

\section{Strategy 10: Avoiding speculation}

What is the use of bringing down the price if it does not reach your target market in the end? There is no clear answer to keep $\neg$ ing speculators from buying, especially since in many cases they are not wealthy individuals buying plots in bulk, but middle class people who want to make little extra money. However, developing a strategy to avoid this cannot be an afterthought and must be carefully developed from the outset. Some potential strategies include:

- Developing strict criteria for buyers to qualify

- Ensuring owner-occupation within a short time period

- Limiting the number of homes that can be purchased by one individual

- Withholding title deed for a period of time, such as 5 years, so owners are unable to re-sell.

\section{Strategy 11: Develop contracts with suppliers}

Given the volatile economic environment, materials prices can skyrocket and turn a healthy project completely unviable. In order to avoid this, develop fixed rate contracts with materials suppliers whenever possible. Some may even have Corporate Social Responsibility programs, so do not be afraid to market the social impact side of the project in order to negotiate better terms.

\section{Housing supply: challenges \\ Challenge 1: Availability of finance}

\section{-Project Finance:}

Housing developments are extremely capital intensive and highly leveraged. Yet it can be difficult to secure debt, especially at reasonable rates, which are a key component of bringing down the cost for the end-user. In fact, the cost of finance is one of the most prohibitive factors in the Rwandan market. The loans and mortgage interest rates of over $15 \%$ in Rwanda are too high to afford for those people with low income wages [9].For the purpose of designing an affordable housing program, affordability can be approached in two ways: by household income categories, and by housing cost categories. Thus the GoR needs to decide and define the key household and housing unit categories to support; options include: a) Support affordability up to the lower to middle class households (say USD100-1000 per month); b) Support only the low-income segment (say USD100-300 household income per month), c) Some instruments to support the lower income and some for the middle income, categories; d) Support specific lowincome employment categories like teachers, police, healthcare staff, or low-paid civil servants in addition to some general income based schemes.

\section{Challenge 2: Volatile economic environment}

Rapid inflation has caused large increases in the cost of materials and land. On average, developers saw their costs in $\neg$ crease by 20 percent in the last 6 months of 2017. It is difficult to maintain a healthy margin with this level of inflation, especially if a large portion of the units were sold off plan at a price that failed to predict the inflation. This is yet another reason to leave a lot of leeway in your model and to understand that while there are many benefits to selling off plan (i.e. selling homes before construct begins or is completed), there are also consequences that should be thought through.

\section{The characteristics of households entering affordable housing}

Households entering the affordable rented sector come from a range of different backgrounds. Looking the case of Rwanda especially the proximity of Kigali, $42 \%$ of new tenancies in affordable homes are provided to families (of which $60 \%$ are single parent families); almost $10 \%$ to elderly households; $35 \%$ to single adults and $14 \%$ to multiple adult households.

The median annual income is around 2.4 Million Rwandan francs for households entering affordable rented housing. This varies greatly by household type however. Two parent families have a median annual income of almost 580000Frwper month equivalence of $\$ 700$ whilst single adults have an average income of around 250000Frw per month. Overall the incomes of households entering affordable housing are significantly high than the average household income of around $1 \mathrm{~m}$ across the population as a whole. This may probably be an indicator of market fail.

\section{Conclusion}

In this study it has reviewed that like elsewhere in Africa, the affordable housing in Rwanda is still an issue. Different thing have to be done to balance the requirements of affordable houses with the household incomes. Indeed, the price of rent or ownership of affordable houses is extremely high compared to the wages and other household incomes. Furthermore, the high loan and mortgage's interest rate in Rwanda is not favour people to own their affordable houses. Only few educated people with good jobs and good household income (Business persons) are able for entering affordable rented housing. But still low cost affordable housing is possible if both public and private sectors work together to minimise all these hindrances towards affordable 
housing.

\section{Recommendations}

As illustrated, the main challenge to obtain affordable housing is high interest rate and big gap between house prices and level of household income. To balance this, the government have to intervene with special fund dedicated to affordable houses that can act as both a subsidy; making the project more financially viable and as a guarantee, allowing a credit constrained housing association to borrow against this amount. On other side, the fund will adjust the interest rate in order to attract more borrowers to invest in affordable housing.

\section{References}

1. Baqutaya S, Ariffin AS, Raji F. Affordable housing policy: Issues and challenges among middle-income groups. International Journal of Social Science and Humanity. 2016;6(6):433-436. doi:10.7763/ IJSSH.2016.V6.686

2. C. Sheldon. Homelessness in a growth economy: Canada's 21st century paradox. A Report for the Sheldon Chumir Foundation for Ethics in Leadership. 2007.

3. CBC. Young buyers drive Toronto condo boom. 2009.

4. Christensen RD, Henry E, Jopling J, Wiedmeier SE. The CBC: reference ranges for neonates. In Seminars in perinatology. 2009;33(1): 3-11. doi:10.1053/j.semperi.2008.10.010

5. COMMUNITIES C. Trends \& Issues in Affordable Housing \& Homelessness.

6. Daniel VE, Florax RJ, Rietveld P. Flooding risk and housing values: An economic assessment of environmental hazard. Ecological Economics. 2009;69(2):355-365. doi:10.1016/j.ecolecon.2009.08.018
7. Ikekpeazu F. New Trends in Low-cost Housing delivery systems in Nigeria: An Overview of the public-private partnership approach. Housing Today. 2004;1(8):30-36.

8. Lawson J, Milligan V, Yates J. Housing supply bonds-a suitable instrument to channel investment towards affordable housing in Australia?. 2012.

9. Mohit M A, Ibrahim M, Rashid YR. Assessment of residential satisfaction in newly designed public low-cost housing in Kuala Lumpur, Malaysia. Habitat international. 2010;34(1):18-27. doi:10.1016/j. habitatint.2009.04.002

10. Nabutola W. Affordable housing in Kenya. In 3rd FIG Regional Conference.2004.

11. Noppen AV. The ABC's of affordable housing in Kenya. Acumen Fund. 2012.

12. Parrillo VN. Understanding race and ethnic relations. Pearson. 2015.

13. Smith MH, Smith G. Bubble, bubble, where's the housing bubble?. Brookings Papers on Economic Activity. 2006;1:1-67.

14. Wallbaum H, Ostermeyer Y, Salzer C, Escamilla EZ. Indicator based sustainability assessment tool for affordable housing construction technologies. Ecological Indicators. 2012;18:353-364. doi. org/10.1016/j.ecolind.2011.12.005

15. Yetgin F, Lepkova N. A comparative analysis on housing policies in Turkey and Lithuania. International Journal of Strategic Property Management. 2007;11(1):47-64.

16. Renaud B. Financial Liberalization and the privatization of housing finance institutions. In International Symposium, The Korea Housing Bank, Seoul. 1997.

17. Nabutola W. Affordable housing-some experiences from Kenya. In FIG Working Week. 2004;1-17. 